\title{
Aluminum and Gallium Hydrazides Derived from N-Aminopyrrole and N-Aminopiperidine
}

\author{
Werner Uhl, Andreas Vogelpohl, and Jutta Kösters \\ Institut für Anorganische und Analytische Chemie der Universität Münster, Corrensstraße 30, \\ D-48149 Münster, Germany \\ Reprint requests to Prof. Dr. W. Uhl. Fax:+49/(0)251/8336660. E-mail: uhlw@uni-muenster.de
}

Z. Naturforsch. 61b, $854-861$ (2006); received March 2, 2006

Dedicated to Professor Wolfgang Jeitschko on the occasion of his $70^{\text {th }}$ birthday

The heterocyclic hydrazine derivatives $\mathrm{N}$-aminopyrrole, $\mathrm{H}_{2} \mathrm{~N}-\mathrm{NC}_{4} \mathrm{H}_{4}$, and $\mathrm{N}$-aminopiperidine, $\mathrm{H}_{2} \mathrm{~N}-\mathrm{NC}_{5} \mathrm{H}_{10}$, reacted with the hydrides $\mathrm{H}-\mathrm{Al}\left(\mathrm{CMe}_{3}\right)_{2}$ or $\mathrm{GaH}_{3} \mathrm{NMe}_{2} \mathrm{Et}$ by the release of elemental hydrogen and the formation of the corresponding aluminum and gallium hydrazides. These products are dimerized in the solid state via $\mathrm{Al}-\mathrm{N}-\mathrm{Al}$ or Ga-N-Ga bridges and possess four-membered $\mathrm{E}_{2} \mathrm{~N}_{2}$ heterocycles with two exocyclic N-N bonds.

Key words: Aluminum, Gallium, Hydrides, Hydrazides, Heterocycles

\section{Introduction}

Organoaluminum and organogallium hydrazides found considerable interest in recent literature, because they may be suitable starting materials for the generation of aluminum or gallium nitrides by thermolysis under relatively mild conditions [1]. Their syntheses were accomplished by various methods such as (i) the treatment of lithium hydrazides with dialkylelement halides by salt elimination [2-5], (ii) the reaction of hydrazines with dialkylelement hydrides or trialkylelement derivatives by the release of hydrogen or alkanes [2, 3, 6-13], or (iii) the application of hydroalumination reactions $[13,14]$. Usually, the dialkylelement hydrazides are dimeric. However, depending on the substituents different structural motifs have been observed with four-, five- and six-membered heterocycles and up to two exocyclic or endocyclic N-N bonds. Few cage compounds containing intact hydrazido groups are also known from literature [15]

Recently, we started with systematic investigations into the thermal behavior of these aluminum and gallium hydrazides. Usually, decomposition occurrs only at temperatures above $200{ }^{\circ} \mathrm{C}$ and depends on the substituents attached to aluminum or gallium and the hydrazido ligands. The mass of the remaining solids corresponds well to the quantitative formation of the corresponding element nitrides. There were strong indications that nitrene or diazene derivatives were released in the course of these decomposition processes by the cleavage of the N-N bonds of the hydrazido ligands. In one case we were able to isolate and characterize an $\mathrm{Al}_{4} \mathrm{~N}_{4}$ heterocubane intermediate weakly coordinated by a diisopropyldiazene molecule [14]. Hydrazines which have one of their nitrogen atoms enclosed in a heterocycle such as aminopyrrole, $\mathrm{H}_{2} \mathrm{~N}-\mathrm{NC}_{4} \mathrm{H}_{4}$, and aminopiperidine, $\mathrm{H}_{2} \mathrm{~N}-\mathrm{NC}_{5} \mathrm{H}_{10}$, should prevent that particular decomposition pathway and, hence, the formation of diazenes. Thus, the thermal behavior of the corresponding hydrazides should give valuable hints for a better understanding of the degradation mechanism. We report here on the syntheses and characterization of aluminum and gallium hydrazides derived from these heterocyclic hydrazines.

\section{Results and Discussion}

Syntheses of aluminum and gallium hydrazides starting with $\mathrm{N}$-aminopyrrole and $\mathrm{N}$-aminopiperidine

Recent reports have shown that the treatment of hydrazines with the corresponding element hydrides is a very effective route for the generation of aluminum and gallium hydrazides $[3,10,11]$. Driving force is the release of elemental hydrogen, and the products are formed in high yields and high purity. Accordingly, di(tert-butyl)aluminum hydride, $\operatorname{HAl}\left(\mathrm{CMe}_{3}\right)_{2}$, reacted with $\mathrm{N}$-aminopyrrole in $n$-hexane at $\mathrm{r}$.t. to yield the corresponding hydrazide 1 (eq. (1)) in a yield of $76 \%$ 
$2\left(\mathrm{Me}_{3} \mathrm{C}\right)_{2} \mathrm{Al}-\mathrm{H}+2 \mathrm{H}_{2} \mathrm{~N}-\mathrm{NR}_{2} \underset{-2 \mathrm{H}_{2}}{\stackrel{ }{\longrightarrow}}$<smiles>CC(C)(C)[Y]1(n2cccc2)[N][Al](C(C)(C)C)(C(C)(C)C)N1n1cccc1</smiles>

1

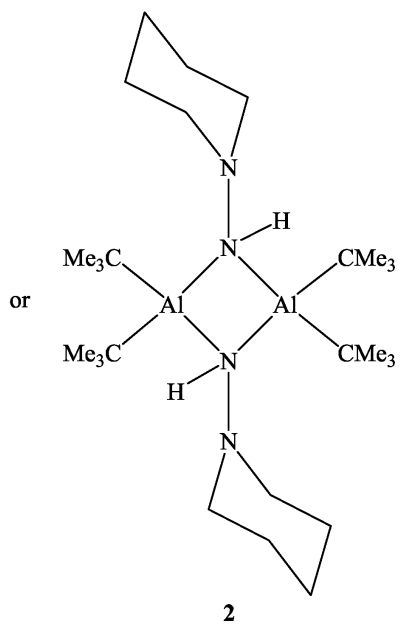

after recrystallization from $n$-hexane. Interestingly, the analogous $\mathrm{N}$-aminopiperidine derivative 2 was insoluble in $n$-hexane. It precipitated from the reaction mixture and was purified by recrystallization from large volumes of toluene. However, the yield (29\%) was relatively low. Both compounds are dimeric possessing $\mathrm{Al}_{2} \mathrm{~N}_{2}$ heterocycles in their molecular cores and two exocyclic N-N bonds. Compound 1 showed the expected ${ }^{1} \mathrm{H}$ NMR spectrum with an $\mathrm{A}_{2} \mathrm{~B}_{2}$ part for the pyrrole hydrogen atoms and singlets for the tert-butyl groups and the $\mathrm{N}-\mathrm{H}$ protons. Probably owing to the dynamic behavior of the six-membered heterocycle, the spectra of $\mathbf{2}$ exhibit broad resonances only, and a clear assignment could not be achieved even with high- and low-temperature data. Preliminary experiments with respect to the thermal stability of both compounds and their decomposition behavior have shown that the compounds are more stable than those derived from monoalkylhydrazines and that the formation of gallium nitride is relatively unfavorable.

Di(tert-butyl)gallium hydride is not applicable for analogous experiments, because it shows a dismutation reaction upon dissolution, and three compounds could be detected by NMR spectroscopy in temperature dependent concentrations: Ga$\left(\mathrm{CMe}_{3}\right)_{3},\left[\mathrm{HGa}\left(\mathrm{CMe}_{3}\right)_{2}\right]_{2}\left[\mathrm{H}_{2} \mathrm{GaCMe}_{3}\right]_{2}$, and [HGa$\left.\left(\mathrm{CMe}_{3}\right)_{2}\right]_{3}$ [16]. Another route for the facile synthesis of aluminum or gallium hydrazides comprises the generation of adducts of dialkylaluminum or dialkylgallium chlorides with the corresponding hydrazines and the treatment of these products with butyllithium. The

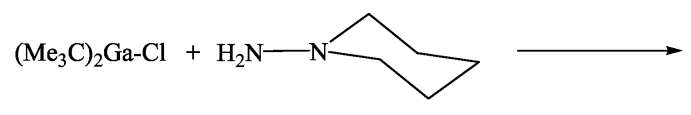<smiles>CC(C)(C)[GeH](Cl)N1CCCCC1</smiles>

(2)<smiles>[R4]C1C=C1</smiles>

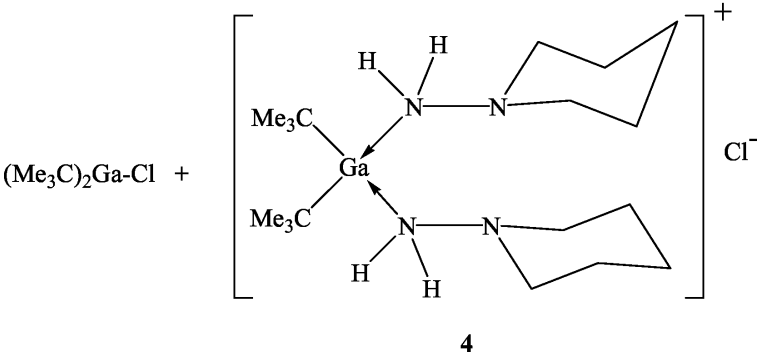

hydrazides are formed by the release of butane and the precipitation of lithium chloride [17-20]. We treated di(tert-butyl)gallium chloride with $\mathrm{N}$-aminopyrrole in order to isolate the corresponding adduct of the heterocyclic hydrazine. A colorless solid precipitated, however, the NMR data were not consistent with the $1: 1$ adduct. We were not able to generate single crystals of that product for an unambiguous characterization, so we do not want to discuss that reaction in more detail. N-Aminopiperidine gave an adduct (3, eq. (2)) in low yield. It was characterized by a crystal structure determination (see below). The NMR spectra of the crystalline product are complicated and verify the occurrence of at least three different products. Obviously, an equilibrium exists in solution, which is summarized in eq. (2) and comprises the starting compound $\left(\mathrm{Me}_{3} \mathrm{C}\right)_{2} \mathrm{GaCl}$, the expected adduct $\left(\mathrm{Me}_{3} \mathrm{C}\right)_{2} \mathrm{GaCl} \cdot \mathrm{NH}_{2}-\mathrm{NC}_{5} \mathrm{H}_{10}(3)$ and the ionic compound $\left[\left(\mathrm{Me}_{3} \mathrm{C}\right)_{2} \mathrm{Ga}\left(\mathrm{NH}_{2}-\mathrm{NC}_{5} \mathrm{H}_{10}\right)_{2}\right] \mathrm{Cl}$ (4). Compound 4 was generated in an NMR experiment by the treatment of di(tert-butyl)gallium chloride with two equivalents of $\mathrm{N}$-aminopiperidine. Comparison of the NMR data verified the formation of $\mathbf{4}$ as a dismutation product of $\mathbf{3}$. A bis(hydrazine)indium cation similar to $\mathbf{4}$ has been obtained in our group only recently [21]. The occurrence of an equilibrium in so- 
<smiles>CC(C)(C)[NH+]1CCCCC1</smiles>

5

$2 \mathrm{H}_{3} \mathrm{Ga}\left(\mathrm{NMe}_{2} \mathrm{Et}\right)+2 \mathrm{H}_{2} \mathrm{~N}-\mathrm{NR}_{2} \stackrel{-2 \mathrm{H}_{2}}{\longrightarrow}$<smiles>[H][Z]1([H])N(n2cccc2)[Y]([H])([H])N1n1cccc1</smiles>

6
Scheme 1.

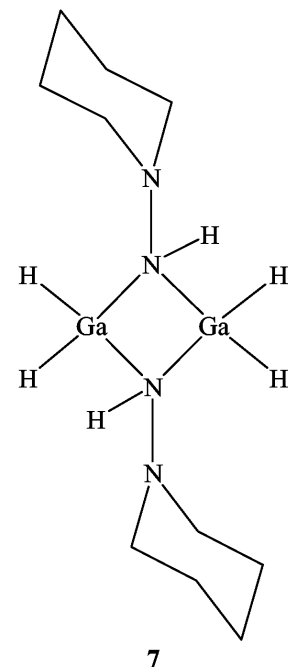

lution prevented the application of $\mathbf{3}$ in any secondary reaction.

Another method for the generation of hydrazides comprises the direct treatment of element chlorides with lithium hydrazides [2-5]. However, the reaction of equimolar quantities of (Li) NH- $\mathrm{NC}_{4} \mathrm{H}_{4}$ and di $($ tertbutyl)gallium chloride did not afford any isolable product. The corresponding reaction of (Li)NH-NC ${ }_{5} \mathrm{H}_{10}$ yielded few crystals of an amino adduct (5, Scheme 1), which was characterized by a crystal structure determination (see below) and does not contain an intact $\mathrm{N}-\mathrm{N}$ bond. The mechanism of its formation is unclear. Further products could not be identified.

Owing to these difficulties we started with investigations into the reactivity of the gallane amine adduct $\mathrm{GaH}_{3} \cdot \mathrm{NMe}_{2} \mathrm{Et}$ towards the respective hydrazines. These reactions should afford interesting gallium hydrazides, which still have hydrogen atoms attached to their gallium atoms and should be suitable starting compounds for the generation of gallium nitride by thermolysis and the release of elemental hydrogen under relatively mild conditions. The reactions with
$\mathrm{N}$-aminopyrrole and $\mathrm{N}$-aminopiperidine (eq. (3)) were conducted in $n$-hexane at -20 to $-25{ }^{\circ} \mathrm{C}$. Colorless substances precipitated in both cases which showed resonances of at least two different $\mathrm{Ga}-\mathrm{H}$ species probably resulting from partial decomposition. They were filtered off, and the products $\mathbf{6}$ and 7 were isolated in yields between 20 and $40 \%$ after concentration and cooling of the filtrate. Both are dimeric possessing $\mathrm{Ga}_{2} \mathrm{~N}_{2}$ heterocycles and two terminal hydrogen atoms attached to each gallium atom. The aminopyrrole derivative 6 shows the expected NMR spectra, those of the aminopiperidine compound 7 show broad resonances owing to the dynamic behavior of the sixmembered piperidine ring. Nevertheless, in this particular case we were able to completely assign resonances to all hydrogen atoms by NMR experiments at different temperatures (see Experimental Section). The hydrogen atoms attached to gallium have resonances at $\delta=5.12$ and 5.36 .

\section{Crystal structure determinations}

The molecular structures of the di(tert-butyl)aluminum compounds $\mathbf{1}$ and $\mathbf{2}$ are depicted in Figs 1 and 2.1 crystallizes with two independent molecules

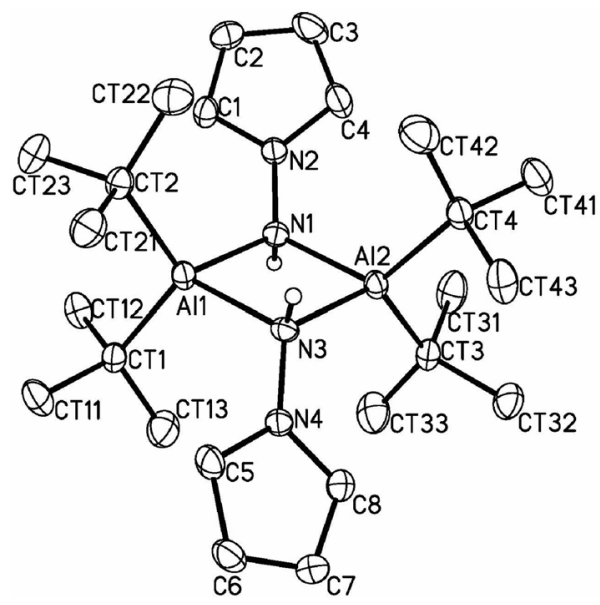

Fig. 1. Molecular structure of compound 1. The ellipsoids are drawn at the $40 \%$ probability level; hydrogen atoms with the exception of $\mathrm{N}-\mathrm{H}$ are omitted. Only one of the two independent molecules is shown. Selected bond lengths [pm] and angles $\left[{ }^{\circ}\right]$ : Al1-N1 200.7(2), Al1-N3 200.0(2), A12-N1 200.4(2), Al2-N3 201.1(2), N1-N2 142.5(2), N3-N4 142.9(2), Al3-N5 200.5(2), Al3-N7 201.2(2), Al4-N5 200.5(2), Al4-N7 200.0(2), N5-N6 143.1(2), N7-N8 143.0(2), N1-Al1-N3 82.77(7), N1-A12-N3 82.55(7), Al1-N1-A12 97.34(8), Al1-N3-A12 97.34(7), N5-A13-N7 82.41(7), N5-Al4-N7 82.72(7), Al3-N5-Al4 97.46(7), Al3-N7-Al4 97.40(7). 


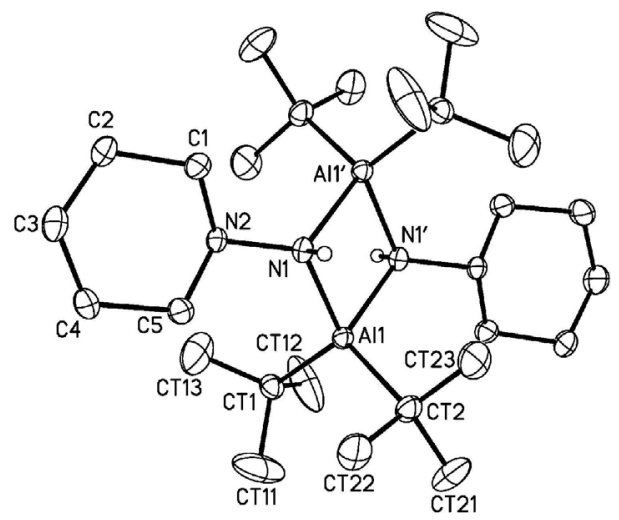

Fig. 2. Molecular structure of compound 2. The ellipsoids are drawn at the $40 \%$ probability level; hydrogen atoms with the exception of $\mathrm{N}-\mathrm{H}$ are omitted. Selected bond lengths [pm] and angles [ ${ }^{\circ}$ ]: Al1-N1 198.3(1), Al1-N1' 198.4(1), N1-N2 145.7(2), Al1-N1-Al1' 95.40(6), N1-A11-N1' 84.60(6); N1' and All' generated by $-x,-y,-z$.

in the asymmetric unit. Both molecules are located on general positions, but they approach a centrosymmetric molecular shape with the N-N bonds and the pyrrole groups on different sides of the central, almost ideally planar $\mathrm{Al}_{2} \mathrm{~N}_{2}$ four-membered rings (torsion angles across the ring bonds $\pm 0.1^{\circ}$ and $\pm 0.7^{\circ}$ ). The heterocycle of $\mathbf{2}$ is located on a crystallographic center of symmetry. The Al-N bond lengths of both compounds differ only slightly (200.6 and $198.4 \mathrm{pm}$ on average) and are in the expected range. Same holds for the N-N bonds (142.9 and $145.7 \mathrm{pm}$ ). The shorter distances of the pyrrole compound may be influenced by the hybridization of the ring nitrogen atoms, which are part of aromatic systems and have an ideally planar surrounding. The most acute angles of the heterocycles are observed at the aluminum atoms (82.6 versus $97.4^{\circ}$ and 84.6 versus $95.4^{\circ}$, respectively).

The molecular structure of compound 3 (Fig. 3) comprises a di(tert-butyl)gallium chloride molecule coordinated by an intact aminopiperidine ligand. The gallium atom has a distorted tetrahedral coordination sphere with the largest angle between the tert-butyl groups $\left(124.5^{\circ}\right)$. As expected, the donor-acceptor bond between gallium and nitrogen is lengthened (208.9 pm) compared to the Ga-N distances in hydrazides in which the nitrogen atoms bear a negative charge (see for comparison $\mathbf{1}$ and 2). All bond parameters are similar to those of gallium-hydrazine adducts published by our group only recently [20]. The N-N bond of aminopiperidine was cleaved upon the formation of compound 5, and an amino adduct of di(tert-

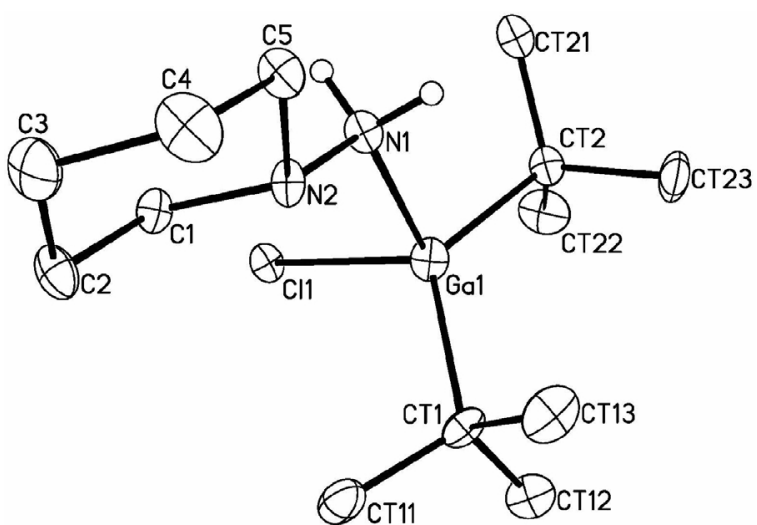

Fig. 3. Molecular structure of compound 3. The ellipsoids are drawn at the $40 \%$ probability level; hydrogen atoms with the exception of $\mathrm{NH}_{2}$ are omitted. Selected bond lengths [pm] and angles [ $\left.{ }^{\circ}\right]$ : $\mathrm{Ga}-\mathrm{Cl} 229.4(1)$, Ga-N1 208.9(5), N1-N2 145.9(6), CT1-Ga-CT2 124.5(3), Ga-N1-N2 117.7(4).

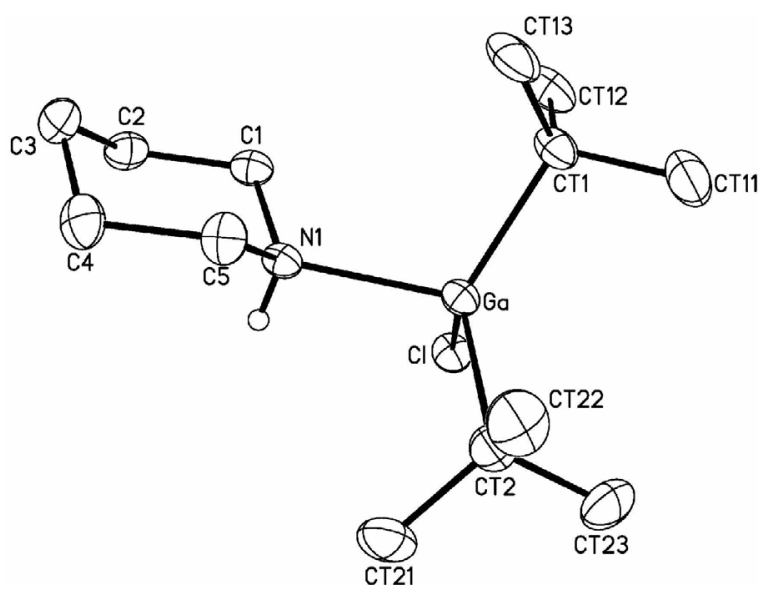

Fig. 4. Molecular structure of compound 5. The ellipsoids are drawn at the $40 \%$ probability level; hydrogen atoms with the exception of $\mathrm{N}-\mathrm{H}$ are omitted. Selected bond lengths [pm] and angles [ $\left.{ }^{\circ}\right]$ : Ga-N1 207.5(2), Ga-Cl 228.35(8), CT1-Ga-CT2 123.6(1).

butyl)gallium chloride resulted in which the amino nitrogen atom is part of the six-membered piperidine ring (Fig. 4). The bond parameters $(\mathrm{Ga}-\mathrm{Cl} 228.4 \mathrm{pm}$, Ga-N $207.5 \mathrm{pm}$ ) are similar to those of compound $\mathbf{3}$ and do not require a detailed discussion [22].

Four-membered $\mathrm{Ga}_{2} \mathrm{~N}_{2}$ rings with two exocyclic $\mathrm{N}-\mathrm{N}$ bonds were observed for the dimeric dihydrido species 6 and 7 (Fig. 5 and 6). Both compounds reside on crystallographic centers of symmetry, thus, the pyrrole or piperidine rings are on different sides of the inner, ideally planar $\mathrm{Ga}_{2} \mathrm{~N}_{2}$ heterocycles. Each gallium atom has a distorted tetrahedral surrounding and is at- 


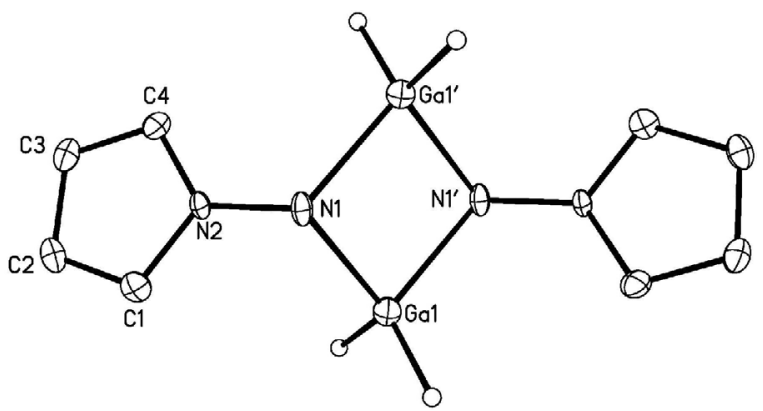

Fig. 5. Molecular structure of compound 6. The ellipsoids are drawn at the $40 \%$ probability level; hydrogen atoms with the exception of $\mathrm{GaH}_{2}$ are omitted. Selected bond lengths [pm] and angles [ ${ }^{\circ}$ ]: Ga1-N1 204.4(5), Ga1-N1' 204.5(5), N1-N2 144.0(6), Ga1-N1-Ga1' 93.5(2), N1-Ga1-N1' 86.5(2); Ga1' and N1' generated by $-x,-y+1$, $-z+1$.

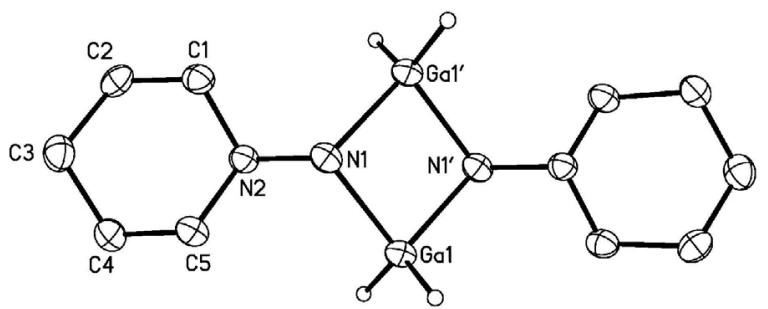

Fig. 6. Molecular structure of compound 7. The ellipsoids are drawn at the $40 \%$ probability level; hydrogen atoms with the exception of $\mathrm{GaH}_{2}$ are omitted. Selected bond lengths [pm] and angles $\left[^{\circ}\right]$ : Ga1-N1 199.6(2), Ga1-N1' 200.2(2), N1-N2 144.9(2), Ga1-H11 145(3), Ga1-H12 134(3), Ga1-N1-Ga1' 92.94(6), N1-Ga1-N1' 87.06(7); Ga1' and N1' generated by $-x+2,-y,-z+2$.

tached to the ring nitrogen atoms and to two terminal hydrogen atoms. The Ga-N bond lengths are in a normal range (204.5 and $199.9 \mathrm{pm})$, the longer ones belong to the pyrrole derivative 6 . The $\mathrm{N}-\mathrm{N}$ bond lengths of both products are quite similar with an average value of $144.5 \mathrm{pm}$.

\section{Experimental Section}

All procedures were carried out under purified argon in dried solvents ( $n$-pentane, cyclopentane, and $n$-hexane over $\mathrm{LiAlH}_{4}$, toluene over $\mathrm{Na}$ /benzophenone). Commercially available 1-amino-piperidine (Aldrich) was degassed prior to use. 1-Aminopyrrole [23], $\mathrm{HAl}\left(\mathrm{CMe}_{3}\right)_{2}$ [16, 24], $\mathrm{ClGa}\left(\mathrm{CMe}_{3}\right)_{2}$ [25], $\mathrm{GaH}_{3} \cdot \mathrm{NMe}_{2} \mathrm{Et}$ [26] were obtained according to literature procedures.

[( $\left.\left.\mathrm{Me}_{3} \mathrm{C}\right)_{2} \mathrm{Al}-\mathrm{N}(\mathrm{H})-\mathrm{NC}_{4} \mathrm{H}_{4}\right]_{2}$ (1): Di(tert-butyl)aluminum hydride $(0.284 \mathrm{~g}, 2.00 \mathrm{mmol})$ was dissolved in $25 \mathrm{ml}$ of $n$-hexane and cooled to $0{ }^{\circ} \mathrm{C}$. 1-Aminopyrrole $(0.158 \mathrm{ml}$, $0.164 \mathrm{~g}, 2.00 \mathrm{mmol}$ ) was added. Gas evolution occurred immediately which was finished after stirring at r.t. for
$3 \mathrm{~h}$. The solution was concentrated in vacuum and cooled to $+5{ }^{\circ} \mathrm{C}$ to get colorless crystals of 1 . Yield: $0.336 \mathrm{~g}(76 \%)$. M. p. (under argon, sealed capillary) $198{ }^{\circ} \mathrm{C}$. - IR (paraffin; $\mathrm{CsBr}$ plates): $\tilde{v}=3192 \mathrm{w}, 3149 \mathrm{vw}, 3102 \mathrm{vw} v(\mathrm{~N}-\mathrm{H})$; 2961 vs, 2926 vs, 2853 vs (paraffin); 2720 vw v(H-Csp $\left.{ }^{3}\right)$; 1463 vs, 1377 s (paraffin); 1354 w, 1302 vw, 1263 vw $\delta(\mathrm{CH}) ; 1189 \mathrm{vw}, 1174 \mathrm{vw}, 1162 \mathrm{vw}, 1085 \mathrm{w}, 1069 \mathrm{w}$, $1004 \mathrm{w}, 963 \mathrm{~m}, 938 \mathrm{w}, 849 \mathrm{w} v(\mathrm{CC}), v(\mathrm{CN}), v(\mathrm{NN}), \delta(\mathrm{CH})$; $812 \mathrm{w} v(\mathrm{NN}) ; 708 \mathrm{~m}$ (paraffin); $606 \mathrm{w}, 586 \mathrm{~m}, 494 \mathrm{w}$, $416 \mathrm{~cm}^{-1} \mathrm{w} v(\mathrm{AlC}), v\left(\mathrm{Al}_{2} \mathrm{~N}_{2}\right) .-{ }^{1} \mathrm{H} \mathrm{NMR}(300 \mathrm{MHz}$, $\left.\mathrm{C}_{6} \mathrm{D}_{6}\right): \delta=1.04\left(\mathrm{~s}, 18 \mathrm{H}, \mathrm{CMe}_{3}\right), 5.18(\mathrm{~s}, 1 \mathrm{H}, \mathrm{NH}), 6.10$ $\left(\mathrm{t},{ }^{3} J_{\mathrm{H}-\mathrm{H}}=3 \mathrm{~Hz}, 2 \mathrm{H}, \mathrm{NCHCH}\right), 6.72\left(\mathrm{t},{ }^{3} J_{\mathrm{H}-\mathrm{H}}=3 \mathrm{~Hz}\right.$, $2 \mathrm{H}, \mathrm{NCHCH}) .-{ }^{13} \mathrm{C}\left\{{ }^{1} \mathrm{H}\right\}$ NMR $\left(50.3 \mathrm{MHz}, \mathrm{C}_{6} \mathrm{D}_{6}\right): \delta=$ 11.3 (AlC), 31.2 (CMe 3 ), 107.9 (NCC), 120.9 (NCC).

$\left[\left(\mathrm{Me}_{3} \mathrm{C}\right)_{2} \mathrm{Al}-\mathrm{N}(\mathrm{H})-\mathrm{NC}_{5} \mathrm{H}_{10}\right]_{2}$ (2): Di(tert-butyl)aluminum hydride $(0.320 \mathrm{~g}, 2.25 \mathrm{mmol})$ was dissolved in $25 \mathrm{ml}$ of $n$-hexane, cooled to $0{ }^{\circ} \mathrm{C}$ and treated with 1 -aminopiperidine $(0.242 \mathrm{ml}, 0.225 \mathrm{~g}, 2.25 \mathrm{mmol})$. The gas evolution was finished after stirring at r.t. for $90 \mathrm{~min}$. A colorless precipitate was formed. The solvent was removed completely in vacuum, and the residue was dissolved in $70 \mathrm{ml}$ of toluene. After concentration the solution was cooled to $-30{ }^{\circ} \mathrm{C}$ to get colorless crystals of 2 . Yield: $0.158 \mathrm{~g}(29 \%)$. M. p. (under argon, sealed capillary) $216{ }^{\circ} \mathrm{C}$. - IR (paraffin; CsBr plates): $\tilde{v}=$ $3116 \mathrm{w} v(\mathrm{NH}) ; 2956 \mathrm{vs}, 2856$ vs (paraffin); $2767 \mathrm{~m}, 2731 \mathrm{w}$, $2698 \mathrm{~m}, 2667 \mathrm{w} v(\mathrm{CH}) ; 1466 \mathrm{vs}, 1378 \mathrm{~s}$ (paraffin); $1354 \mathrm{~m}$, 1339 w, 1320 w, 1278 w, 1266 w, 1258 w $\delta\left(\mathrm{CH}_{3}\right) ; 1228$ w, 1179 vw, $1151 \mathrm{w}, 1103 \mathrm{w}, 1072 \mathrm{vw}, 1060 \mathrm{w}, 1035 \mathrm{~m}, 1001 \mathrm{w}$, $986 \mathrm{vw}, 971 \mathrm{vw}, 921 \mathrm{~s}, 874 \mathrm{~s}, 859 \mathrm{~s} v(\mathrm{CC}), v(\mathrm{CN}), v(\mathrm{NN})$, $\delta(\mathrm{CH}) ; 810 \mathrm{~s}, 775 \mathrm{~s} v(\mathrm{NN}) ; 728 \mathrm{w}$ (paraffin); $627 \mathrm{~s}, 598 \mathrm{~s}$, $519 \mathrm{vw}, 457 \mathrm{~s}, 410 \mathrm{~cm}^{-1} \mathrm{w} v(\mathrm{AlC}), v\left(\mathrm{Al}_{2} \mathrm{~N}_{2}\right), \delta\left(\mathrm{C}_{3} \mathrm{C}\right)$. ${ }^{1} \mathrm{H}$ NMR (300 MHz, $\mathrm{C}_{6} \mathrm{D}_{6}$ ): $\delta=1.12$ (br.), $1.27\left(\mathrm{~s}, \mathrm{CMe}_{3}\right.$ ), 1.70 (br.), 2.80 (br.), 3.13 (br.). $-{ }^{13} \mathrm{C}\left\{{ }^{1} \mathrm{H}\right\}$ NMR (50.3 MHz, $\left.\mathrm{C}_{6} \mathrm{D}_{6}\right): \delta=10.2\left(\mathrm{AlCMe}_{3}\right), 22.8(\mathrm{NCCC}), 26.2$ (NCCC), $33.0\left(\mathrm{AlCMe}_{3}\right), 64.1$ ( $\left.\mathrm{NCCC}\right)$.

$\left(\mathrm{Me}_{3} \mathrm{C}\right)_{2} \mathrm{GaCl}\left(\mathrm{NH}_{2}-\mathrm{NC}_{5} \mathrm{H}_{10}\right)$ (3): $\mathrm{Di}($ tert-butyl)gallium chloride $(0.538 \mathrm{~g}, 2.45 \mathrm{mmol})$ was dissolved in $25 \mathrm{ml}$ of $n$-pentane and treated with 1-aminopiperidine $(0.270 \mathrm{ml}$, $0.251 \mathrm{~g}, 2.50 \mathrm{mmol})$ at r.t. Small quantities of a colorless solid precipitated after $5 \mathrm{~min}$. The mixture was cooled to $+5{ }^{\circ} \mathrm{C}$ over night to obtain colorless needles of the product. The solvent was removed, and the needles were dried in vacuum. The residue was recrystallized twice from toluene for further purification. Yield: $0.181 \mathrm{~g}$ ( $23 \%$ based on the chloride). M.p. (under argon, sealed capillary) $122{ }^{\circ} \mathrm{C}$ (dec.). - IR (paraffin; CsBr plates): $\tilde{v}=3233 \mathrm{w}, 3162 \mathrm{w}, 3099 \mathrm{w} v(\mathrm{NH}) ; 2857$ vs (paraffin); $2706 \mathrm{w} v(\mathrm{CH}) ; 1579 \mathrm{w} ; 1458 \mathrm{vs}, 1378 \mathrm{~s}$ (paraffin); $1323 \mathrm{w}$, 1299 vw, 1267 w, 1243 vw $\delta\left(\mathrm{CH}_{3}\right) ; 1189$ w, 1157 vw, $1125 \mathrm{vw}, 1098 \mathrm{w}, 1060 \mathrm{w}, 1039 \mathrm{vw}, 1010 \mathrm{w}, 940 \mathrm{vw}$, $860 \mathrm{vw} v(\mathrm{CC}), v(\mathrm{CN}), v(\mathrm{NN}), \delta(\mathrm{CH}) ; 813 \mathrm{w}, 772 \mathrm{w} v(\mathrm{NN})$; $722 \mathrm{w}$ (paraffin); $642 \mathrm{vw}, 578 \mathrm{~cm}^{-1} \mathrm{vw} v(\mathrm{GaC}), v(\mathrm{GaN})$, $\delta\left(\mathrm{C}_{3} \mathrm{C}\right) .-{ }^{1} \mathrm{H}$ NMR $\left(300 \mathrm{MHz}, \mathrm{C}_{6} \mathrm{D}_{6}\right): \delta=0.81$ (br., $2 \mathrm{H}$ 
Table 1. Crystal data, data collection, and structure refinement.

\begin{tabular}{|c|c|c|c|c|c|c|}
\hline & 1 & 2 & 3 & 5 & 6 & 7 \\
\hline \multicolumn{7}{|l|}{$\overline{\text { Crystal data }}$} \\
\hline Empirical formula & $\mathrm{C}_{24} \mathrm{H}_{46} \mathrm{Al}_{2} \mathrm{~N}_{4}$ & $\mathrm{C}_{26} \mathrm{H}_{58} \mathrm{Al}_{2} \mathrm{~N}_{4}$ & $\mathrm{C}_{13} \mathrm{H}_{30} \mathrm{ClGaN}_{2}$ & $\mathrm{C}_{13} \mathrm{H}_{29} \mathrm{ClGaN}$ & $\mathrm{C}_{8} \mathrm{H}_{14} \mathrm{Ga}_{2} \mathrm{~N}_{4}$ & $\mathrm{C}_{10} \mathrm{H}_{26} \mathrm{Ga}_{2} \mathrm{~N}_{4}$ \\
\hline$M_{r}$ & 444.61 & 480.72 & 319.56 & 304.54 & 305.68 & 341.78 \\
\hline Crystal system & monoclinic & monoclinic & triclinic & rhombohedral & monoclinic & monoclinic \\
\hline Space group [28] & $P 2_{1} / c ;$ no. 14 & $P 2_{1} / n ;$ no. 14 & $P \overline{1} ;$ no. 2 & $R \overline{3}$; no. 148 & $P 2_{1} / n ;$ no. 14 & $P 2_{1} / c$; no. 14 \\
\hline$a[\mathrm{pm}]$ & $1799.4(2)$ & $917.0(1)$ & $643.89(3)$ & $2344.1(2)$ & $459.5(1)$ & $1192.0(2)$ \\
\hline$b[\mathrm{pm}]$ & $1904.8(2)$ & $1644.4(2)$ & $1127.69(4)$ & $2344.1(2)$ & $790.5(2)$ & $712.9(1)$ \\
\hline$c[\mathrm{pm}]$ & $1661.0(2)$ & $997.0(1)$ & $1297.72(6)$ & $1578.8(2)$ & $1555.1(4)$ & $961.8(2)$ \\
\hline$\alpha\left[^{\circ}\right]$ & 90 & 90 & $110.421(3)$ & 90 & 90 & 90 \\
\hline$\beta\left[{ }^{\circ}\right]$ & $109.323(2)$ & $104.184(2)$ & $99.235(3)$ & 90 & $97.030(6)$ & $112.099(3)$ \\
\hline$\gamma\left[{ }^{\circ}\right]$ & 90 & 90 & $99.503(3)$ & 120 & 90 & 90 \\
\hline$V\left(10^{-30} \mathrm{~m}^{3}\right)$ & $5372(1)$ & $1457.5(3)$ & $846.36(6)$ & $7513(2)$ & $560.7(3)$ & $757.2(2)$ \\
\hline$\rho_{\text {calc }}\left[\mathrm{g} \mathrm{cm}^{-3}\right]$ & 1.099 & 1.095 & 1.254 & 1.212 & 1.811 & 1.499 \\
\hline$Z$ & 8 & 2 & 2 & 18 & 2 & 2 \\
\hline$F(000)$ & 1952 & 536 & 340 & 2916 & 304 & 352 \\
\hline$\mu\left(\mathrm{Mo}-\mathrm{K}_{\alpha}\right)\left[\mathrm{cm}^{-1}\right]$ & 0.125 & 0.120 & 1.769 & 1.789 & 4.773 & 3.542 \\
\hline \multicolumn{7}{|l|}{ Data collection } \\
\hline$T[\mathrm{~K}]$ & 153 & 153 & 120 & 153 & 153 & 153 \\
\hline Unique reflections & 10654 & 3531 & 2800 & 2402 & 1675 & 2305 \\
\hline Reflections $I>2 \sigma(I)$ & 5722 & 2486 & 2068 & 2104 & 1212 & 1754 \\
\hline \multicolumn{7}{|l|}{ Refinement } \\
\hline Refined parameters & 581 & 155 & 168 & 155 & 67 & 85 \\
\hline \multicolumn{7}{|l|}{ Final $R$ values } \\
\hline$R 1 I>2 \sigma(I)^{\mathrm{a}}$ & 0.0408 & 0.0453 & 0.0666 & 0.0280 & 0.0627 & 0.0297 \\
\hline$w R 2^{\mathrm{b}}$ (all data) & 0.0771 & 0.1218 & 0.1747 & 0.0838 & 0.1651 & 0.0620 \\
\hline$\underline{\rho_{\text {fin }}(\max / \min )\left[\mathrm{e}^{-3}\right]}$ & $0.312 /-0.213$ & $0.369 /-0.283$ & $1.104 /-0.706$ & $1.127 /-0.196$ & $2.020 /-0.802$ & $0.659 /-0.324$ \\
\hline
\end{tabular}

${ }^{\mathrm{a}} R=\Sigma\left(|| F_{\mathrm{o}}|-| F_{c}||\right) / \Sigma\left|F_{\mathrm{o}}\right| ;{ }^{\mathrm{b}} w R 2=\left\{\left[\Sigma w\left(F_{\mathrm{o}}^{2}-F_{c}^{2}\right)^{2}\right] / \Sigma\left[w\left(F_{\mathrm{o}}^{2}\right)^{2}\right]\right\}^{1 / 2}$.

$\mathrm{NCH}_{2} \mathrm{CH}_{2} \mathrm{CH}_{2}$ ), 1.20 (br., $4 \mathrm{H}, \mathrm{NCH}_{2} \mathrm{CH}_{2} \mathrm{CH}_{2}$ ), 1.33 (s, $18 \mathrm{H}, t \mathrm{Bu}$ ), 1.80 (br., $4 \mathrm{H}, \mathrm{NCH}_{2} \mathrm{CH}_{2} \mathrm{CH}_{2}$ ), 3.57 (br., $2 \mathrm{H}, \mathrm{NH}_{2}$ ); further resonances occurred which were assigned to the dismutation products $\mathrm{ClGa}\left(\mathrm{CMe}_{3}\right)_{2}(\delta=$ $1.28)$ and $\left[\left(\mathrm{Me}_{3} \mathrm{C}\right)_{2} \mathrm{Ga}\left(\mathrm{NH}_{2}-\mathrm{NC}_{5} \mathrm{H}_{10}\right)_{2}\right] \mathrm{Cl} 4[\delta=0.68$ $\left(\mathrm{NCH}_{2} \mathrm{CH}_{2} \mathrm{CH}_{2}\right), 1.17\left(\mathrm{NCH}_{2} \mathrm{CH}_{2} \mathrm{CH}_{2}\right), 1.58\left(\mathrm{CMe}_{3}\right)$, $\left.2.25\left(\mathrm{NCH}_{2} \mathrm{CH}_{2} \mathrm{CH}_{2}\right), 4.86\left(\mathrm{NH}_{2}\right)\right]$.

$\left(\mathrm{Me}_{3} \mathrm{C}\right)_{2} \mathrm{GaCl}\left(\mathrm{HNC}_{5} \mathrm{H}_{10}\right) \quad$ (5): $\quad$ 1-Aminopiperidine $(0.050 \mathrm{~g}, 0.50 \mathrm{mmol})$ was dissolved in $5 \mathrm{ml}$ of $n$-hexane, cooled to $-80{ }^{\circ} \mathrm{C}$ and treated with $0.31 \mathrm{ml}$ of a solution of $n$-butyllithium in $n$-hexane $(1.6 \mathrm{M}, 0.50 \mathrm{mmol})$. The mixture was warmed to r.t. and added to a solution of di(tert-butyl)gallium chloride $(0.112 \mathrm{~g}, 0.51 \mathrm{mmol})$ in $10 \mathrm{ml}$ of toluene at $-50{ }^{\circ} \mathrm{C}$. The yellow solution was warmed to r.t., and toluene was removed in vacuum. Recrystallization from cyclopentane yielded a colorless solid which consisted of at least three different products (resonances of tert-butyl groups in the ${ }^{1} \mathrm{H}$ NMR spectrum at $\delta=1.20,1.29$ and 1.33). Repeated recrystallisation from cyclopentane yielded few crystals of compound $5\left({ }^{1} \mathrm{H}\right.$ NMR: $\left.\delta=1.30\left(\mathrm{CMe}_{3}\right)\right)$.

$\mathrm{H}_{2} \mathrm{GaN}(H)-\mathrm{NC}_{4} \mathrm{H}_{4}$ (6): $\mathrm{GaH}_{3} \cdot \mathrm{NMe}_{2} \mathrm{Et}(0.15 \mathrm{ml}, 0.15 \mathrm{~g}$, $1.03 \mathrm{mmol}$ ) was dissolved in $20 \mathrm{ml}$ of $n$-pentane and cooled to $-20{ }^{\circ} \mathrm{C}$. 1 -Aminopyrrole $(0.08 \mathrm{ml}, 0.084 \mathrm{~g}, 1.03 \mathrm{mmol})$ was added. The solution was slowly warmed to r.t. (12 h). Small quantities of a colorless solid precipitated which were filtered off. The filtrate was concentrated in vacuum and cooled to $-20{ }^{\circ} \mathrm{C}$ to get colorless crystals of the product 6 . Yield: $0.057 \mathrm{~g}(36 \%)$. M.p. (under argon, sealed capillary) no melting until $320^{\circ} \mathrm{C}$, color change from colorless to redbrown. - IR (paraffin; CsBr plates): $\tilde{v}=3348$ vw, $3208 \mathrm{w}$ $v(\mathrm{NH}) ; 2926$ vs (paraffin); 1984 w, $1941 \mathrm{~m}$,br. $v(\mathrm{GaH})$; $1616 \mathrm{vw}, 1538 \mathrm{vw}$ (aromatic ring); $1462 \mathrm{vs,} 1377$ vs (paraffin); $1303 \mathrm{w}, 1170$ vw $\delta(\mathrm{CH}) ; 1081 \mathrm{~m}, 1069 \mathrm{~m} \mathrm{v}(\mathrm{CN})$; $961 \mathrm{~m}, 877 \mathrm{w}, 854 \mathrm{w} v(\mathrm{NN}) ; 715 \mathrm{~s}$ (paraffin); $680 \mathrm{~m}, 586 \mathrm{~m}$, $535 \mathrm{w}, 497 \mathrm{w} v(\mathrm{GaN}) .-{ }^{1} \mathrm{H}$ NMR $\left(200 \mathrm{MHz}, \mathrm{C}_{6} \mathrm{D}_{6}\right): \delta=$ 4.09 (s, 1H, NH), 5.12 (s, 2H, br., $\mathrm{GaH}_{2}$ ), 6.09 (pseudo-t, $2 \mathrm{H}$, $\mathrm{NCHCH}$ ), 6.38 (pseudo-t, 2H, NCHCH). $-{ }^{13} \mathrm{C}\left\{{ }^{1} \mathrm{H}\right\} \mathrm{NMR}$ $\left(50.3 \mathrm{MHz}, \mathrm{C}_{6} \mathrm{D}_{6}\right): \delta=107.0 \mathrm{NCC}, 119.8 \mathrm{NCC}$.

$\mathrm{H}_{2} \mathrm{GaN}(\mathrm{H})-\mathrm{NC}_{5} \mathrm{H}_{10}$ (7): $\mathrm{GaH}_{3} \cdot \mathrm{NMe}_{2} \mathrm{Et}(0.44 \mathrm{ml}, 0.44 \mathrm{~g}$, $3.02 \mathrm{mmol}$ ) was dissolved in $40 \mathrm{ml}$ of $n$-hexane and cooled to $-25^{\circ} \mathrm{C}$. 1 -Aminopiperidine $(0.33 \mathrm{ml}, 0.306 \mathrm{~g}, 3.06 \mathrm{mmol})$ was added. The solution was slowly warmed to r.t. (12 h). Small quantities of a colorless solid precipitated which were filtered off. The filtrate was concentrated in vacuum and cooled to $-20{ }^{\circ} \mathrm{C}$ to get colorless crystals of the product 7. Yield: $0.104 \mathrm{~g}(20 \%)$. M. p. (under argon, sealed capillary) $105{ }^{\circ} \mathrm{C}$. - IR (paraffin; CsBr plates): $\tilde{v}=3406 \mathrm{vw}$, br., 3147 w, br. $v(\mathrm{NH}) ; 2923$ vs, 2854 vs (paraffin); 1907 m,br. $v(\mathrm{GaH}) ; 1589 \mathrm{vw} ; 1463 \mathrm{vs}, 1377 \mathrm{~s}$ (paraffin); $1303 \mathrm{vw}$, 1272 vw $\delta(\mathrm{CH}) ; 1151 \mathrm{vw}, 1099$ vw $v(\mathrm{CN}), v(\mathrm{CC}) ; 924 \mathrm{w}$, $890 \mathrm{w}, 859 \mathrm{w} v(\mathrm{NN}) ; 715 \mathrm{~s}$ (paraffin); $696 \mathrm{~m}, 589 \mathrm{~m}$, $556 \mathrm{~cm}^{-1} \mathrm{~m} \mathrm{v}(\mathrm{GaN}) .-{ }^{1} \mathrm{H}$ NMR $\left(400 \mathrm{MHz}, \mathrm{C}_{6} \mathrm{D}_{6}\right)$ : 
$\delta=0.66$ (pseudo-q, $1 \mathrm{H}$, axial $\mathrm{H}$ of $\mathrm{NCH}_{2} \mathrm{CH}_{2} \mathrm{CH}_{2}$ ), 1.14 (pseudo-t, $2 \mathrm{H}$, axial $\mathrm{H}$ of $\left.\mathrm{NCH}_{2}\right), 1.2(3 \mathrm{H}$, overlapping resonances of equatorial $\mathrm{H}$ of $\mathrm{NCH}_{2} \mathrm{CH}_{2} \mathrm{CH}_{2}$ and equatorial $\mathrm{H}$ atom of $\mathrm{NCH}_{2} \mathrm{CH}_{2} \mathrm{CH}_{2}$ ), 1.52 (pseudo-q, $2 \mathrm{H}$, axial $\mathrm{H}$ atom of $\mathrm{NCH}_{2} \mathrm{CH}_{2} \mathrm{CH}_{2}$ ), $2.39(\mathrm{~s}, 1 \mathrm{H}, \mathrm{NH}), 3.17$ (pseudo-d, 2H, equatorial $\mathrm{H}$ of $\left.\mathrm{NCH}_{2}\right), 5.36\left(\mathrm{~s}, 2 \mathrm{H}, \mathrm{GaH}_{2}\right)$. $-{ }^{13} \mathrm{C}\left\{{ }^{1} \mathrm{H}\right\}$ NMR $\left(100.3 \mathrm{MHz}, \mathrm{C}_{6} \mathrm{D}_{6}\right): \delta=22.9$ (NCCC), 26.0 (NCC), 59.9 (NCC).

Crystal structure determinations: Single crystals were obtained by cooling of saturated solutions in different solvents (1: $n$-hexane, $+5{ }^{\circ} \mathrm{C} ; 2$ : toluene, $-30{ }^{\circ} \mathrm{C} ; 3$ : toluene, $+5{ }^{\circ} \mathrm{C}$; 5: cyclopentane, $-30{ }^{\circ} \mathrm{C} ; 6$ : $n$-pentane, $-20^{\circ} \mathrm{C} ; 7: n$-hexane, $-20^{\circ} \mathrm{C}$ ). Data collections were performed on a Bruker Smart Apex diffractometer employing graphite-monochromated Mo-K $\mathrm{K}_{\alpha}$ radiation. The structures were solved by direct methods and refined by full matrix least-squares calculations based on $\mathrm{F}^{2}$ [27]. With the exception of N-H protons, the hydrogen atoms were calculated on ideal positions and refined by the riding model. The hydrogen atoms at- tached to $\mathrm{Ga}$ of compound 6 were refined on ideal positions (Ga-H $150 \mathrm{pm})$. Crystal data, data collection parameters and details of the structure refinement are given in Table 1 . The crystallographic data of all compounds (excluding structure factors) were deposited with the Cambridge Crystallographic Data Centre, CCDC-600072 (1), -600073 (2), -600074 (3), -600075 (5), -600076 (6), and -600077 (7). Copies of the data can be obtained free of charge on application to The Director, CCDC, 12 Union Road, Cambridge CB21EZ, UK (Fax: int.code+(1223)336-033; e-mail for inquiry: fileserv@ccdc.cam.ac.uk). Compound 1 crystallized with two independent molecules in the asymmetric unit. The molecules of $\mathbf{2}, \mathbf{6}$, and $\mathbf{7}$ are located on crystallographic centers of symmetry.

\section{Acknowledgements}

We are grateful to the Deutsche Forschungsgemeinschaft and the Fonds der Chemischen Industrie for generous financial support.
[1] S. J. Pearton, F. Ren, Adv. Mater. 12, 1571 (2000), D. K. Gaskill, N. Bottka, M. C. Lin, J. Crystal Growth 77, 418 (1986); H. Okumura, S. Misaura, S. Yoshida, Appl. Phys. Lett. 59, 1058 (1991); S. Miyoshi, K. Onabe, N. Ohkouchi, H. Yaguchi, R. Ito, S. Fukatsu, Y. Shiraki, J. Crystal Growth 124, 439 (1992); R. T. Lee, G. B. Stringfellow, J. Electron Mater. 28, 963 (1999); M. Mizuta, S. Fujieda, Y. Matsumoto, T. Kawamura, Jpn. J. Appl. Phys. 25, L 945 (1986); S. Fujieda, M. Mizuta, Y. Matsumoto, Jpn. J. Appl. Phys. 26, 2067 (1987); H. Okumura, S. Yoshida, S. Misawa, E. Sakuma, J. Crystal Growth 120, 114 (1992); V. Lakhotia, D. A. Neumayer, A. H. Cowley, R. A. Jones, J. G. Ekerdt, Chem. Mater. 7, 546 (1995).

[2] H. Nöth, T. Seifert, Eur. J. Inorg. Chem. 602 (2002); H. Nöth, T. Seifert, Eur. J. Inorg Chem. 1931 (1998).

[3] B. Luo, W. L. Gladfelter, Chem. Commun. 825 (2000).

[4] D. A. Neumayer, A. H. Cowley, A. Decken, R. A. Jones, V. Lakhotia, J. G. Ekerdt, Inorg. Chem. 34, 4698 (1995).

[5] W. Uhl, J. Molter, R. Koch, Eur. J. Inorg. Chem. 2021 (1999).

[6] Y. Kim, J. H. Kim, J. E. Park, H. Song, J. T. Park, J. Organomet. Chem. 454-546, 99 (1997).

[7] D. Cho, J. E. Park, B.-J. Bae, K. Lee, B. Kim, J. T. Park, J. Organomet. Chem. 592, 162 (1999).

[8] D. W. Peters, M. P. Power, E. D. Bourret, J. Arnold, Chem. Commun. 753 (1998).

[9] D. W. Peters, E. D. Bourret, M. P. Power, J. Organomet. Chem. 582, 108 (1999).

[10] W. Uhl, J. Molter, B. Neumüller, Inorg. Chem. 40, 2011 (2001).
[11] W. Uhl, J. Molter, B. Neumüller, Organometallics 19, 4422 (2000).

[12] J. S. Silverman, C.D. Abernethy, R. A. Jones, A. H. Cowley, Chem. Commun. 1645 (1999).

[13] R. J. Wehmschulte, P. P. Power, Inorg. Chem. 35, 2717 (1996).

[14] W. Uhl, J. Molter, B. Neumüller, Chem. Eur. J. 7, 1510 (2001).

[15] Review: W. Uhl, Springer Verlag, Berlin-HeidelbergNew York, S. 41 (2003).

[16] W. Uhl, L. Cuypers, R. Graupner, J. Molter, A. Vester, B. Neumüller, Z. Anorg. Allg. Chem. 627, 607 (2001).

[17] W. Uhl, J. Molter, R. Koch, Eur. J. Inorg. Chem. 2255 (2000).

[18] W. Uhl, J. Molter, B. Neumüller, W. Saak, Z. Anorg. Allg. Chem. 626, 2284 (2000).

[19] W. Uhl, J. Molter, W. Saak, Z. Anorg. Allg. Chem. 625, 321 (1999).

[20] W. Uhl, C. H. Emden, J. Organomet. Chem. 690, 1529 (2005).

[21] W. Uhl, C. H. Emden, G. Geiseler, K. Harms, Z. Anorg. Allg. Chem. 629, 2157 (2003).

[22] Aminoadducts with dialkylgalliumchlorides: M. R. Churchill, C. H. Lake, O. T. Beachley (Jr.), M. J. Noble, J. Coord. Chem. 49, 309 (2000); Y. Koide, J. A. Francis, S. G. Bott, A. R. Barron, Polyhedron 17, 983 (1998); M. Niemeyer, T. J. Goodwin, S. H. Risbud, P. P. Power, Chem. Mater. 8, 2745 (1996).

[23] W. Flitsch, U. Krämer, H. Zimmermann, Chem. Ber. 102, 3267 (1969).

[24] W. Uhl, Z. Anorg. Allg. Chem. 570, 37 (1989). 
[25] G. G. Hoffmann, D. Hellert, M. Warren, J. Organomet. Chem. 444, 21 (1993).

[26] R. Dorn, M. Müller, J. Lorberth, G. Zimmermann, H. Protzmann, W. Stolz, E. O. Göbel, Mat. Sci. Eng. B 17, 25 (1993).

[27] SHELXTL-Plus, REL. 4.1; Siemens Analytical X-
RAY Instruments Inc.: Madison, WI, 1990. Sheldrick, G. M. SHELXL-97, Program for the Refinement of Structures; Universität Göttingen, Germany (1997).

[28] T. Hahn, (ed.): International Tables for Crystallography, Space-Group Symmetry, Vol. A, Kluwer Academic Publishers, Dordrecht-Boston-London (1989). 